\title{
PENATAAN KAWASAN EMBUNG AIK BUAL MELALUI PENGUATAN MEDIA INTERPRETASI WISATA
}

\author{
Maiser Syaputra ${ }^{1)^{\star}}$, Irwan Mahakam Lesmono Aji1), Indriyatno ${ }^{11}$. \\ 1)Jurusan Kehutanan, Fakultas Pertanian, Universitas Mataram \\ *e-mail: syaputra.maiser@gmail.com
}

\begin{abstract}
ABSTRAK. Sarana interpretasi kepariwisataan adalah semua fasilitas informasi yang memungkinkan agar aktivitas kepariwisataan dapat hidup dan berkembang serta dapat memberikan pelayanan pada wisatawan untuk memenuhi kebutuhan informasi yang beraneka ragam. Sarana interpretasi wisata juga dapat diartikan sebagai bagian kelengkapan daerah tujuan wisata yang diperlukan untuk melayani kebutuhan informasi wisatawan dalam menikmati perjalanan wisatanya.Pembangunan sarana interpretasi wisata di daerah tujuan wisata maupun objek wisata tertentu harus disesuaikan dengan kebutuhan wisatawan baik secara kuantitatif maupun kualitatif. Sarana wisata secara kuantitatif menunjuk pada jumlah sarana wisata yang harus disediakan, dan secara kualitatif yang menunjukkan pada mutu informasi yang diberikan dan yang tercermin pada kepuasan wisatawan yang memperoleh pelayanan informasi. Dalam hubungannya dengan jenis sarana interpretasi wisata di daerah tujuan wisata khususnya kawasan hutan telah disusun suatu standar kebutuhan yang baku, sehingga pemegang ijin atau penyedia sarana wisata tinggal memilih atau menentukan jenis sarana yang akan disediakannya, hal ini tercantum dalam Perdirjen PHKA No.5 tahun 2015 meliputi papan informasi, papan interpretasi, papan peringatan, dan papan petunjuk arah. Penataan kawasan embung Aik bual melalui penguatan media interpretasi wisata dilakukan melalui beberapa rangkaian kegiatan, diawali dengan obeservasi potensi kawasan dan wawancara terhadap aktor kunci, diikuti dengan menyelenggarakan penyuluhan bersama pengelola mengenai teknik pembuatan media interpretasi serta diakhiri dengan pendampingan pembuatan materi media interpretasi.
\end{abstract}

Kata kunci: penataan, interpretasi, aik bual

\section{PENDAHULUAN}

Aik bual merupakan salah satu desa yang terletak di Kabupaten Lombok Tengah, Provinsi Nusa Tenggara Barat sekaligus berada di kaki Gunung Rinjani dengan beragam potensi sumberdaya alam danwisatadi dalamnyatermasuk embung. Keberadaan embung ini kemudian menciptakan atraksi embung Bual yang saat ini cukup diminati oleh wisatawan. Pengembangan wisata embung Aik bual belum lama ini dilakukan sehingga masih membutuhkan dukungan dari berbagai pihak termasuk dalam memenuhi atribut sarana kepariwisataan seperti sarana interpretasi.

Sarana interpretasi kepariwisataan adalah semua fasilitas informasi yang memungkinkan agar aktivitas kepariwisataan dapat hidup dan berkembang serta dapat memberikan pelayanan pada wisatawan untuk memenuhi kebutuhan informasi yang beraneka ragam. Sarana interpretasi wisata juga dapat diartikan sebagai bagian kelengkapan daerah tujuan wisata yang diperlukan untuk melayani kebutuhan informasi wisatawan dalam menikmati perjalanan wisatanya.Pembangunan 
sarana interpretasi wisata di daerah tujuan wisata maupun objek wisata tertentu harus disesuaikan dengan kebutuhan wisatawan baik secara kuantitatif maupun kualitatif. Sarana wisata secara kuantitatif menunjuk pada jumlah sarana wisata yang harus disediakan, dan secara kualitatif yang menunjukkan pada mutu informasi yang diberikan dan yang tercermin pada kepuasan wisatawan yang memperoleh pelayanan. Dalam hubungannya dengan jenis sarana interpretasi wisata di daerah tujuan wisata khususnya kawasan hutan telah disusun suatu standar kebutuhan yang baku, sehingga pemegang ijin atau penyedia sarana wisata tinggal memilih atau menentukan jenis sarana yang akan disediakannya, hal ini tercantum dalam PerdirjenPHKA No.5 tahun 2015 meliputi papan informasi, papan interpretasi, papan peringatan, dan papan petunjuk arah.

Penataan kawasan embung aik bual melalui penguatan media interpretasi wisata dilakukan melalui beberapa rangkaian kegiatan, diawali dengan obeservasi potensi kawasan dan wawancara terhadap aktor kunci, diikuti dengan menyelenggarakan penyuluhan bersama pengelola mengenai teknik pembuatan media interpretasi serta diakhiri dengan pendampingan pembuatan materi media interpretasi.

\section{Tujuan dan Manfaat}

Tujuan dilaksanakannya kegiatan pengabdian ini adalah : (1).Memfasilitasi pengelola embung Aik bual untuk mengidentifikasi potensi pengembangan media interpretasi kawasan dan (2). Memberikan penyuluhan mengenai metode pembuatan media interpretasi wisata.

Sementara manfaat yang akan diperoleh dari hasil pengabdian ini adalah : (1). Diperolehnya informasi potensi pengembangan media interpretasi kawasan wisata yang lengkap yang dapat dijadikan dasar bagi pengelola untuk mengelola embung Aik bual dan (2). Pengetahuan pengelola embung Aik bual mengenai pengembangan media interpretasi wisata bertambah.

\section{SOLUSI DAN TARGET LUARAN \\ Permasalahan dan Solusi yang Ditawarkan \\ Permasalahan}

Media interpretasi wisata seperti yang tertuang pada Perdirjen PHKA No.5 tahun 2015 meliputi papan informasi, papan interpretasi, papan peringatan, dan papan petunjuk arah merupakan salah satu sarana kelengkapan kepariwisataan yang penting untuk menjamin aktivitas pengunjung terutama dalam mengakses informasi dapat berjalan secara efektif dan efisien.Belum tersedianya media interpretasi wisata di kawasan embung Aik bual menyebabkan pengunjung kurang optimal maupun kesulitan didalam mengakses informasi, sehingga pada prakteknya informasi tidak sampai dengan baik. Dengan demikian kawasan wisata embung Aik bual dapat dikatakanbelum memiliki keutuhan tidak hanya dalam konteks pembangunan destinasi wisata, namun juga peran dan kontribusinya dalam memperkaya pengetahuan pengunjung. Berdasarkan permasalahan tersebut, penataan kawasan embung aik bual melalui penguatan media interpretasi wisata menjadi strategis untuk dilakukan.

\section{Solusi yang Ditawarkan}

Penataan kawasan embung aik bual melalui penguatan media interpretasi wisata dilakukan melalui beberapa rangkaian kegiatan, diawali dengan obeservasi potensi kawasan dan wawancara terhadap aktor kunci, diikuti dengan menyelenggarakan penyuluhan bersama pengelola mengenai 
teknik pembuatan media interpretasi serta diakhiri dengan pendampingan pembuatan materi media interpretasi.

\section{Target Luaran}

Target luaran dari kegiatan ini adalah(1)Artikel IImiah dengan status accepted pada jurnal nasional berISSN /prosiding dari seminar / publikasi on-line.(2). Bagian buku ajar mata Manajemen Ekowisata dan Jasa Lingkungan (3). Masyarakat di HKm Aik Bual memiliki pengetahuan dan kemampuan dalam bidang pengembangan media interpretasi wisata.

\section{METODE}

\section{Waktu dan Tempat}

Kegiatan penataan kawasan embung Aik bual melalui penguatan media interpretasi wisatadilaksanakan pada bulan Juli-September 2018, berlokasi di kawasan HKm Aik Bual, KecamatanKopang, Lombok Tengah, Provinsi Nusa Tenggara Barat.

\section{Peserta Kegiatan}

Peserta dalam kegiatan pelatihan ini adalah perwakilan pengelola maupun masyarakat yang mengelola wisata embung Aik bual berjumlah 30 orang.

\section{Metode Pelaksanaan Kegiatan}

Metode yang digunakan dalam kegiatan ini yaitu:

A. Pra Kegiatan

a. Persiapan

Persiapan yang dimaksud meliputi : penyelesain urusan administrasi, komunikasi awal dengan kelompok sasaran, diskusi rencana kegiatan bersama kelompok sasaran yang bertujuan untuk mendapatkan saran serta masukan mengenai teknis pelaksanaan kegiatan, serta finalisasi instrument untuk observasi lapangan maupunpenyuluhan.

b. Konsolisdasi Tim

Memastikan kesiapan tim terhadap tugas dan perannya masing-masing, menyepakati jadwal pelaksanaan kegiatan.

c. Observasi Lapangan

Melakukan pengamatan dan eksplorasi informasi di lapangan secara langsung oleh tim bersama pengelola dan aktor kunci. Mengumpulkan informasi mengenai potensi wisata alam di embung Aik bual, meliputi ragam objek wisata alam, objek wisata pendukung, atraksi wisata, atraksi budaya, sejarah, religi, keanekaragaman hayati sekitar, serta aksesibilitas kawasan.

B. Penyuluhan

Melakukan pertemuanbersama penerima manfaat untuk menyampaikan materi penyuluhan dalam hal ini mengenai penguatan media interpretasi wisata.Pendekatan kegiatan menggunakan metode partisipasi aktif, yaitu melibatkan anggota kelompok yang menjadi penerima manfaat, dalam proses-proses kegiatan baik dalam penyampaian materi maupun implementasi kegiatan. Materi yang disajikan sesuai dengan urgensi kegiatan dan dilakukan oleh tim sesuai dengan bidang ilmu/keahliannya. 

C. Penyusunan laporan akhir
Menyusun laporan akhir dan laporan penggunaan anggaran

\section{HASIL DAN PEMBAHASAN}

Interpretasi adalah suatu kegiatan yang mengandung makna pendidikan, bertujuan untuk mengungkap arti dan hubungan keterkaitan dengan memanfaatkan objek, baik melalui pengalaman langsung maupun melalui media ilustrasi atau visual. Interpretasi juga merupakan sebuah seni dan ilmu dalam menghubungkan pengunjung, seperti turis, tamu, klien dan pelanggan dengan ide, sumber daya dan kesempatan untuk belajar. Media interpretasi wisata berperan sebagai pengganti interpretasi personal yang menyampaikan informasi dan edukasi pada waktu tertentu, sehingga media interpretasi dilapangan pada umumnya berbentuk papan atau plang.

Kegiatan pengabdian terbagi menjadi beberapa tahap. Tahapan pra kegiatan bertujuan untuk mempersiapkan segala hal terkait pelaksanaan kegiatan penyuluhan, dalam tahap pra kegiatan dilakukan proses observasi awal untuk melihat kondisi dan permasalahan yang dihadapi oleh kelompok masyarakat sasaran dalam hal ini pengelola Embung Aik Bual, termasuk memperkenalkan secara formal kegiatan yang akan dilaksanakan, proses penyamaan pendapat, dan kesepakatan mengenai tujuan kegiatan. Adapun hal yang dibahas dalam tahapan pra kegiatan ini antara lain:

1. Mengupas dan mengenali berbagai potensi objek dan daya tarik wisata alam Embung Aik Bual.

2. Peninjauan lokasi, melakukan observasi lapangan, analisa dan pemetaan objek dan daya tarik wisata alam Embung Aik Bual.

3. Pertemuan dengan pihak pengelola objek dan daya tarik wisata alam Embung Aik Bual dan pihak Pemerintah Desa. Mendengar permasalahan dari segi kepengurusan lembaga dan administrasi.

4. Melakukan diskusi terfokus bersama pengelola objek dan daya tarik wisata alam Embung Aik Bual ditingkat tapak.

Hasil dan output dari tahapan pra kegiatan diformulasikan kedalam materi penyuluhan, materi terfokus pada penguatan media interpretasi wisata alam yang memenuhi kaidah yang berlaku serta informatif. Penyampaian materi penyuluhan diawali dengan pembukaan dan pengantar oleh pihak pengelola objek wisata alam Embung Aik Bual. Selanjutnya diikuti dengan pengantar dan perkenalan dari pihak penyuluh. Guna menunjang pencapaian tujuan penyuluhan yang efektif dan efesien, maka penyampaian materi penyuluhan dipilih metode partisipasi aktif dan dipadukan dengan diskusi terfokus dan tanya jawab. Adapun isi materi penyuluhan terdiri dari tiga pokok bahasan yaitu sebagai berikut :

1. Peran media interpretasi dalam pengembangan pariwisata alam.

2. Aturan dan kaidah pembangunan sarana prasarana pendukung wisata.

3. Teknik pembuatan media interpretasi pendukung wisata.

Setelah semua materi disampaikan oleh penyuluh, maka selanjutnya masuk pada sesi diskusi/tanya jawab dengan peserta penyuluhan. Dalam sesi ini penyuluh mencatat dan menampung pertanyaan maupun pengalaman yang dikemukan oleh peserta dan berusaha memberikan jawaban dan tanggapan sehingga peserta mampu memahami solusi dari permasalahan yang diungkapkan. Pada kegiatan ini dikembangkan komunikasi dua arah dalam 
bentuk diskusi (tanya jawab) mengenai materi penyuluhan. Sesi diskusi yang juga merupakan inti dari kegiatan penyuluhan. Beberapa masalah yang berkembang adalah sebagai berikut :

Tabel 1. Hasil kegiatan diskusi

\begin{tabular}{|c|c|c|}
\hline No & Materi Diskusi & Hasil Diskusi \\
\hline 1 & $\begin{array}{l}\text { Minimnya dana } \\
\text { operasional } \\
\text { pengelola wisata } \\
\text { Embung Aik Bual, } \\
\text { sehingga kegiatan } \\
\text { yang direncanakan } \\
\text { tidak dapat } \\
\text { terealisasikan }\end{array}$ & $\begin{array}{l}\text { Pengelola wisata Embung Aik Bual perlu jeli melihat peluang } \\
\text { pendanaan yang ada, salah satunya melalui skema kerjasama } \\
\text { CSR. Melalui skema kerjasama CSR pengelola bisa mendapatkan } \\
\text { donasi dari berbagai perusahaan maupun badan usaha. Dari dana } \\
\text { yang diperoleh nantinya dapat dilakukan pemenuhan kebutuhan } \\
\text { media interpresi di lokasi. }\end{array}$ \\
\hline 2 & $\begin{array}{l}\text { Kurangnya } \\
\text { ketersediaan data } \\
\text { potensi kawasan } \\
\text { dan objek wisata } \\
\text { yang ada sehingga } \\
\text { kurang mampu } \\
\text { menangkap } \\
\text { peluang yang ada }\end{array}$ & $\begin{array}{l}\text { Untuk membuat media interpretasi dibutuhkan data dalam jumlah } \\
\text { yang mencukupi. Untuk mengetahui data potensi kawasan secara } \\
\text { menyeluruh dibutuhkan kegiatan inventarisasi. Kegiatan } \\
\text { inventarisasi tidak dapat berjalan maksimal apabila dilakukan oleh } \\
\text { satu pihak saja, sehingga dibutuhkan upaya pendampingan secara } \\
\text { khusus, pendampingan dapat dilakukan oleh akademisi maupun } \\
\text { LSM. Pendampingan akademisi dapat dilakukan oleh universitas } \\
\text { dengan cara mengarahkan mahasiswa praktek, magang maupun } \\
\text { tugas akhir }\end{array}$ \\
\hline 3 & $\begin{array}{l}\text { Menetukan } \\
\text { prioritas } \\
\text { penempatan media } \\
\text { interpretasi }\end{array}$ & $\begin{array}{l}\text { Prioritas penempatan media interpretasi wisata memiliki makna } \\
\text { sebagai lokasi unggulan atau lokasi penempatan utama. Prioritas } \\
\text { penempatan media interpretasi wisata dapat ditentukan melalui } \\
\text { beberapa cara diantaranya melihat pada keberadaan objek wisata } \\
\text { terpopuler, tempat berkumpulnya massa, maupunpada lokasi yang } \\
\text { terlihat oleh banyak orang. }\end{array}$ \\
\hline 4 & $\begin{array}{l}\text { Perawatan media } \\
\text { informasi }\end{array}$ & $\begin{array}{l}\text { Faktor yang mempengaruhi usia pemakian sarpras media } \\
\text { interpretasi adalah faktor konstruksi atau penggunaan bahan, faktor } \\
\text { lingkungan meliputi iklim dan cuaca serta vandalisme yaitu kegiatan } \\
\text { pengunjung yang mengakibatkan kerusakan pada media } \\
\text { interpretasi. }\end{array}$ \\
\hline 5 & $\begin{array}{l}\text { Peran media } \\
\text { interpretasi dalam } \\
\text { kegiatan promosi } \\
\text { wisata }\end{array}$ & $\begin{array}{l}\text { Kegiatan promosi merupakan hal penting dalam pengembangan } \\
\text { objek wisata. Untuk dapat memperluas pemasaran objek wisata } \\
\text { dapat dilakukan berbagai langkah, salah satunya melalui media } \\
\text { internet. Keberadaan media interpretasi yang menarik akan } \\
\text { menimbulakan keinginan pengunjung untuk berbagi gambar di } \\
\text { media sosial. }\end{array}$ \\
\hline
\end{tabular}

Berdasarkan hasil pemantauan dan pengamatan yang dilaksanakan pada saat pelaksanaan kegiatan penyuluhan dapat dikatakan bahwa penyuluhan ini berhasil, ini tercermin dari kesungguhan dan keseriusan peserta penyuluhan dalam mengikuti dan menanggapi setiap meteri yang diberikan penyuluh. Beberapa hasil yang diperoleh peserta dari kegiatan penyuluhan ini sekaligus parameter keberhasilan kegiatan ini antara lain: 
1. Bertambahnya pengetahuan dan keterampilan peserta dalam memahami peran media interpretasi dalam pengembangan objek wisata alam.

2. Tumbuhnya motivasi dari peserta untuk meningkatkan kemampuan kerja

3. Transfer ilmu pengatahuan dari penyuluh kepada peserta sehingga ilmu yang dimiliki tersebut dapat bermanfaat bagi peserta khususnya dalam penggunaan media interpretasi dalam penataan kawasan wisata.

Kondisi ini memberikan indikator adanya hubungan antara pokok materi yang diberikan dengan kebutuhan atau masalah yang dihadapi oleh peserta penyuluhan. Fenomena yang ditunjukan oleh peserta penyuluh seperti dikemukan diatas, hanya dapat digunakan sebagai petunjuk adanya kemampuan peserta dalam aspek kognitif dan aspek afektif, akan tetapi belum dapat dijadikan tolak ukur untuk mengetahui apakah materi yang dibutuhkan benar-benar telah diterapkan oleh peserta penyuluhan, oleh karena itu sangat diperlukan pemantauan lebih lanjut pada waktu yang akan datang

\section{KESIMPULAN DAN SARAN}

Kesimpulan yang diperoleh dari kegiatan penyuluhan ini adalah peserta mampu memahami peran media interpretasi dalam penataan kawasan wisata alam yang memenuhi kaidah yang berlaku serta informatif, melalui keberhasilan dalam mengidentifikasi kebutuhan data, potensi sumber pendanaan dan penentuan prioritas penempatan media. Dari segi kegiaan penyuluhan, keberhasilan kegiatan dapat dilihat dari antusiasme dan respon positif peserta selama kegiatan berlangsung. Selain itu ditunjukkan pula dengan komitmen peserta yang ingin menjalin komunikasi jangka panjang dengan penyuluh.

Adapun saran dari kegiatan penyuluhan ini antaralain perlu diadakannya kegiatan pemantauan pada masa mendatang, untuk dapat melihat konsistensi tindakan peserta penyuluhan dan faktor-faktor yang mempengaruhinya. Selain itu peserta perlu pula diajak untuk studi kunjungan ke kawasan wisata alam lainnya yang lebih maju untuk memberi gambaran dan pemahaman lebih mendalam mengenai penataan kawasan wisata alam melalui keberadaan media interpretasi.

\section{REFERENSI}

Direktur Jenderal Perlindungan Hutan Dan Konservasi Alam. 2015. Perubahan Atas Peraturan Direktur Jenderal Perlindungan Hutan Dan Konservasi Alam Nomor : P. 3/lv-Set/2011 Tentang Pedoman Penyusunan Desain Tapak Pengelolaan Pariwisata Alam Di Suaka Margasatwa, Taman Nasional, Taman Hutan Raya Dan Taman Wisata Alam.

Rahmat J. 2005. Metode Penelitian Komunikasi. Rosdakarya. Bandung.

Tilden F. 1957. Interpreting Our Heritage. The University of North Corolina Press. New York 